\title{
Preliminary Investigation of Some Organic Agro-wastes Amendment on Soil Microbial Activity and Yield of Hausa Potato (Solenostemon rotundifolius Poir) in South Eastern Nigeria
}

\author{
E. F. Iwoh ${ }^{1, *}$, O. D. Onyegbula ${ }^{1}$, I. U. Ibok $^{2}$ \\ ${ }^{1}$ National Root Crops Research Institute Umudike, P.M.B. 7006 Umuahia, Abia State, Nigeria. \\ ${ }^{2}$ Akwa Ibom State Polytechnic Ikot Osurua, Akwa Ibom State, Nigeria.
}

\begin{abstract}
How to cite this paper: E. F. Iwoh, O. D. Onyegbula, I. U. Ibok. (2020) Preliminary Investigation of Some Organic Agro-wastes Amendment on Soil Microbial Activity and Yield of Hausa Potato (Solenostemon rotundifolius Poir) in South Eastern Nigeria. International Journal of the Science of Food and Agriculture, 4(4), 435-441.

DOI: $10.26855 /$ ijfsa.2020.12.010
\end{abstract}

Received: October 14, 2020

Accepted: November 12, 2020

Published: November 30, 2020

*Corresponding author: E. F. Iwoh, National Root Crops Research Institute Umudike, P.M.B. 7006 Umuahia, Abia State, Nigeria.

Email: georgeiwoh1@gmail.com

\begin{abstract}
This research was conducted to investigate some agro organic wastes amendment on soil microbial activity, growth and yield, using randomized complete block design in four replications with Hausa potato (solenostemon rotundifolius) as the test plant. The trail involved four treatments: non-fertilized (control), cassava peel (CP), empty palm bunch (EPB), saw dust (SD) and rice mill waste (RMW). Soil samples were collected from the surface $(0-20 \mathrm{~cm})$ soil for microbial analysis before and after treatments at monthly intervals for 4 months. The data were subjected to Duncan new multiple range test at $\mathrm{p} \leq 0.05$. Cultural morphology and biochemical identification were carried out using standard microbiological techniques. Results obtained showed that bacterial population was higher than the fungal population in all the treatments. Saw dust (SD) induced the highest increase in microbial population of (114.66 x10 $\pm 2.88 \mathrm{cfu} / \mathrm{g}$ ), followed by cassava peel (CP) $109.43 \times 10^{6} \mathrm{cfu} / \mathrm{g}$, rice mill waste (RMW) $104.00 \times 10^{6} \mathrm{cfu} / \mathrm{g}$, empty palm bunch (EPB) $78.63 \times 10^{6} \pm 2.51 \mathrm{cfu} / \mathrm{g}$ and control $61.33 \times 10^{2} \pm 1.19 \mathrm{cfu} / \mathrm{g}$, respectively. Similar effect was observed on fungal population which CP gave the highest $\left(24.66 \times 10^{2} \pm 1.73 \mathrm{cfu} / \mathrm{g}\right)$, followed by SD $\left(23.33 \times 10^{2} \pm 1.25 \mathrm{cfu} / \mathrm{g}\right)$, RMW $\left(19.53 \times 10^{2} \pm 1.65 \mathrm{cfu} / \mathrm{g}\right)$ and EPB $\left(17.00 \times 10^{2} \pm 1.16\right.$ $\mathrm{cfu} / \mathrm{g})$ and control $\left(11.33 \times 10^{2} \pm 1.19 \mathrm{cfu} / \mathrm{g}\right)$. Microorganisms isolated and their percentage occurrence include: Staphylococcus aureus (100\%), Proteus mirabilis (100\%), Escherichia coli (100\%), Micrococcus varians (100\%), Pseudomonas aeruginosa (100\%), Bacillus cereus (80\%), Aspergillus niger (80\%), Rhizopus spp (80\%), Penicillium spp (80\%), Lactococcus lactis (60\%), Acinetobacter calcoaceticus (60\%), Fusarium (60\%), Enterobacter cloacae (53\%), Salmonella sp (40\%), Mucor spp (40\%), and Aureobasidium spp (40\%). The Hausa potato yield and stem height obtained with the use of 5 t/ha saw dust (SD) was significantly higher than that of $5 \mathrm{t} / \mathrm{ha}$ cassava peel (CP) and $5 \mathrm{t} / \mathrm{ha}$ rice mill waste (RMW) as well as $5 \mathrm{t} / \mathrm{ha}$ empty palm bunch (EPB).
\end{abstract}

\section{Keywords}

Organic Agro-Wastes, Hausa Potato, Microbial Activity, Microorganisms, Physicochemical, Soil, Yield

\section{Introduction}

Organic agro-waste is defined as wastes which are produced from various agricultural activities. This includes manures, bedding, plant stalks, hulls, leaves, and vegetable matter. It contains essential nutrients needed for improvement 
of soil fertility, plant growth and yield [1]. However, proper utilization of these organic wastes by farmers is still poor despite their high nutrient composition [2]. Increasing the sustainability of cropping systems involves the reduction of agrochemical and fertilizer inputs through the reliance on soil ecosystem processes and biological interactions for the provision of plant nutrients [3]. Management of soil fertility through organic fertilizers has always been a pivotal principle of sustainable agriculture. There is need to consider soil microbial processes as they are crucial for plant nutrient supply given their central role in soil organic matter decomposition and nutrient dynamics [4]. Better understanding of the microbial processes that take place in soil under organic fertilization could help identify the main drivers determining nutrient availability in order to improve crop growth. Extensive use of chemical fertilizers in relation to organic fertilizers has led to decrease in soil organic carbon and soil quality [5]. Thus there is a need to utilize these plant residues such as Cassava peel, Empty palm bunch, saw dust and Rice mill waste etc., to save fertilizers and maintain a satisfactory level of soil fertility, and this can be practicable and adopted by farmers when the approach has considered some microbiological studies. The objective of this study was therefore to investigate the effects of organic agro wastes amendment on microbial activity, growth and yield of Hausa potato (solenostemon rotundifolius poir) in an ultisol of south eastern Nigeria.

\section{Materials and Methods}

\subsection{Study Site}

The experiment was carried out on a loamy soil at the agricultural experimental field of National Root Crops Research Institute Umudike, Nigeria (longitude $07^{0} 33^{\prime} \mathrm{E}$, latitude $05^{\circ} 29^{\prime} \mathrm{N}$ and altitude $122 \mathrm{M}$ ). Umudike is in the low-land humid tropics of south eastern Nigeria. The experiment was conducted in April and July 2019, as a randomized complete block design (RCBD), with four replications. Each plot size measured $15 \mathrm{~m}^{2}$ (3 m x $5 \mathrm{~m}$ ); with $1 \mathrm{~m}$ spacing between the plots. The test plant used in the experiment was Hausa potato (solenostemon rotundifolius poir) Treatments comprised Control (without fertilization), cassava peel at $5 \mathrm{t} / \mathrm{ha}$, Saw dust (SD) at $5 \mathrm{t} / \mathrm{ha}$, empty palm bunch (EPB) at $5 \mathrm{t} / \mathrm{ha}$ and Rice mill waste (RMW) at $5 \mathrm{t} / \mathrm{ha}$; and were uniformly distributed. The treatments were allowed to incubate for one week before planting the test crop. Hausa potato (solenostemon rotundifolius) was planted on the mounds at a depth of $5 \mathrm{~cm}$ and spacing of $0.7 \mathrm{~m}$ between rows and $0.25 \mathrm{~m}$ within row, respectively.

\subsection{Soil sampling}

Soil sampling was conducted in accordance with the method of [6]. Soil samples were collected from the study site before treatment and four times after treatments at monthly intervals beginning from May 2018 to August 2018. Soil auger was used to collect top soil sample from depth of 0-20 cm at four randomly selected locations in each of the plots. Composite samples were collected from each plot and stored in a sterile polypropylene bag and kept cool using coolers during field sampling. The composite samples were homogenized and sieved twice using meshes $(2.0$ and $0.2 \mathrm{~mm})$ in order to remove stone and plant debris. Samples collected were subsequently processed within 24-48 hour.

\subsection{Physicochemical analysis of Soil samples}

Physicochemical properties of each soil sample were determined using the methods of [7] and the Association of Official Analytical Chemists [8]. Parameters for consideration were $\mathrm{pH}$, organic carbon, organic matter, total nitrogen $(\mathrm{N})$, available phosphorus and exchangeable potassium (K).

\subsection{Microbiological analysis}

One gram (1g) of each of the soil samples was weighed and agitated in $9 \mathrm{~mL}$ of distilled water, to dislodge the organisms from the soil particles. An aliquot of $1 \mathrm{~mL}$ was serially transferred from each sample into series of test tubes containing sterilized distilled water to obtain dilution of $10^{-1}$ and $10^{-10}$. The microbial population was enumerated, which involved determination and count of total viable microorganisms in the experiment using the method of dilution on specific solid media spread plate technique series of $10^{-}$fold serial dilution. Aliquot $(0.1 \mathrm{ml})$ of $10^{-2}, 10^{-4}, 10^{-6}$ and $10^{-8}$ was inoculated into nutrient agar plated in triplicates [9]. Total soil fungi were enumerated by inoculating aliquots $(0.1 \mathrm{~mL})$ and determined using Sabouraud dextrose agar (SDA) supplemented with streptomycin $(1 \mathrm{mg} / 100 \mathrm{~mL})$ to suppress bacterial growth with the diluted soil samples of $10^{-3}[10]$. The plates were all incubated aerobically at room temperature $\left(30^{\circ} \mathrm{C}\right)$ for 24hours (bacteria) and 96 hours (fungi). The resulting colonies were counted and recorded as colony forming units per gram (CFU/g) using colony counter. The counts were characterized based on cultural characteristics, staining reaction and biochemical tests.

\subsection{Plant height measurement}

Measurement was done after one month of planting, with 95\% germination; three plants were selected and labeled specifically for data collection, at monthly interval. Plant height was measured using a meter rule from the surface of 
the soil to the tip of the tallest leaf [11]

\subsection{Yield determination}

Hausa potato yield was determined through the weight of tubers collected from two middle rows of each plot (expressed in $\mathrm{t} / \mathrm{ha}$ ), and was done at the end of the growing season (4 MAP).

\subsection{Statistical analysis}

The data were subjected to an analysis of variance (ANOVA Statistica SPSS 5), using a GENSTAT and the significant effects between individual-factor level and interaction means were separated using Duncan new multiple range test (DNMRT) at $P \leq 0.05$ level.

\section{Results and Discussion}

Results of the soil physicochemical properties of the experimented soil showed that the experimental soil pH is moderately acidic with a textural class of clay loam, moisture content highest recorded in SD, highest in organic carbon content and organic matter was recorded in EPB, while highest in total $\mathrm{N}$ and available $\mathrm{P}$ and exchangeable $\mathrm{K}$ was recorded in $\mathrm{CP}$ at $P \leq 0.05$ (Table 1). This is in line with [12] the application of organic manures significantly increased the soil organic carbon content whereas, chemical fertilizers had no effect.

Total heterotrophic bacterial population recorded during the growing season was at maximum during the $2^{\text {nd }}$ month (May) of sampling, followed by $3^{\text {rd }}$ month (June), $4^{\text {th }}$ month (July) and then $1^{\text {st }}$ month (April), respectively. The maximum bacterial counts were recorded in a plot amended with $5 \mathrm{t} / \mathrm{ha}$ saw dust $(114.66 \times 106 \pm 2.18 \mathrm{CFU} / \mathrm{g})$ and at minimum in control plot $\left(61.33 \times 10^{6} \pm 2.00 \mathrm{CFU} / \mathrm{g}\right)$. A significant variation in bacterial population was found between treated plots and control $P \leq 0.05$; (Table 2). Saw dust (SD) provided organic substrates that proliferated bacterial population and activities in the soil, as they breakdown soil organic matter and multiply in the soil, which accounted for the highest bacterial count that peaked in the $2^{\text {nd }}$ month of sampling. The increase in saw dust (SD) amended plot might be as a result of suitable conditions which acted as a good substratum for microbial activity. Similar short-term increases in microbial biomass have been reported previously by [13] [14] and attributed to the supply of organic Carbon substrates. Other researchers have also shown that incorporation of organic amendments such as poultry manure increased soil microbial population, enzymatic and microbial diversity [15] [16]. Saw dust promoted biological and microbial activities, which accelerated the breakdown of organic substances in the soil with evidence in relatively high carbon content and enzyme activities. Further increase was recorded with plot amended with cassava peel (CP), which also might be attributed to the symbiotic and mycorrhizal relationships with soil microorganisms. Also, [17] reported that soils under organic farming had enhanced microbial functional diversity in comparison with the soils of conventional farming. In general, the bacterial population was higher than the fungal population throughout the sampling period. Bacteria were also the most sensitive microbial group to the different amendment; also, bacteria have much shorter turnover time than fungi and can react faster to the environmental changes in soil. According to [18] organic manure application promotes bacteria population when compared with fungi population in the soil. Another report by [19] indicates that addition of animal or green manures on organic farms provide a significantly greater input of organic carbon, which increased bacterial populations, while the use of excessive chemical fertilizers reduced microbial functional diversity and enzymatic activity in the soil.

Table 1. Soil physicochemical properties of the study soil in 2019 cropping season

\begin{tabular}{cccccc}
\hline & \multicolumn{5}{c}{ Soil samples } \\
Parameters & C & CP & EPB & SD & RMW \\
\hline Soil pH & $5.55 \pm 0.26^{\text {bc }}$ & $5.35 \pm 0.12^{\mathrm{e}}$ & $5.12 \pm 0.16^{\mathrm{a}}$ & $5.38 \pm 0.18^{\mathrm{b}}$ & $5.28 \pm 0.18^{\mathrm{b}}$ \\
Moisture content (\%) & $47.87 \pm 0.73^{\mathrm{a}}$ & $43.34 \pm 0.13^{\mathrm{d}}$ & $44.36 \pm 33^{\mathrm{c}}$ & $46.83 \pm 0.93^{\mathrm{b}}$ & $45.63 \pm 0.93^{\mathrm{b}}$ \\
Organic Carbon (\%) & $1.84 \pm 0.09^{\mathrm{c}}$ & $2.16 \pm 0.03^{\mathrm{b}}$ & $2.59 \pm 0.09^{\mathrm{a}}$ & $1.88 \pm 0.08^{\mathrm{c}}$ & $1.77 \pm 0.08^{\mathrm{c}}$ \\
Organic Matter (\%) & $2.68 \pm 0.09^{\mathrm{c}}$ & $2.81 \pm 0.05^{\mathrm{b}}$ & $2.83 \pm 0.09^{\mathrm{a}}$ & $2.49 \pm 0.03^{\mathrm{d}}$ & $2.49 \pm 0.03^{\mathrm{d}}$ \\
Total Nitrogen N (\%) & $0.34 \pm 0.07^{\mathrm{d}}$ & $0.68 \pm 0.04^{\mathrm{a}}$ & $0.58 \pm 0.09^{\mathrm{b}}$ & $0.45 \pm 0.08^{\mathrm{c}}$ & $0.55 \pm 0.08^{\mathrm{c}}$ \\
Available P (Mg/kg) & $13.13 \pm 0.95^{\mathrm{c}}$ & $18.45 \pm 0.09^{\mathrm{a}}$ & $16.90 \pm 0.13^{\mathrm{b}}$ & $13.59 \pm 0.09^{\mathrm{d}}$ & $12.59 \pm 0.09^{\mathrm{d}}$ \\
Exchangeable K (Cmol/kg) & $0.01 \pm 0.81^{\mathrm{d}}$ & $0.29 \pm 0.29^{\mathrm{a}}$ & $0.18 \pm 0.63^{\mathrm{b}}$ & $0.02 \pm 0.03^{\mathrm{c}}$ & $0.05 \pm 0.03^{\mathrm{c}}$ \\
\hline
\end{tabular}

Values show mean of triplicate analysis \pm standard deviation figure with superscripts in the row which shows significantly different according to Duncan new multiple range test at $\mathrm{P} \leq 0.05$

$\mathrm{C}=$ control; $\mathrm{CP}=$ Cassava peel; $\mathrm{EPB}=$ Empty palm bunch; $\mathrm{SD}=$ saw dust; RMW= Rice mill waste 
Table 2. Effect of different treatment applications on total heterotrophic bacterial mean count (CFU/g) in 2019 cropping season

\begin{tabular}{ccccc}
\hline & & Sampling period & & July \\
\hline Treatments & April & May & June & $61.33 \times 10^{6} \pm 1.62^{\mathrm{a}}$ \\
Control & $61.33 \times 10^{6} \pm 3.05^{\mathrm{a}}$ & $61.33 \times 10^{6} \pm 2.00^{\mathrm{a}}$ & $61.33 \times 10^{6} \pm 2.51^{\mathrm{a}}$ & $96.00 \times 10^{6} \pm 2.30^{\mathrm{e}}$ \\
CP & $92.43 \times 10^{6} \pm 1.52^{\mathrm{d}}$ & $109.43 \times 10^{6} \pm 2.5^{\mathrm{d}}$ & $98.43 \times 10^{6} \pm 1.73^{\mathrm{d}}$ & $74.00 \times 10^{6} \pm 2.10^{\mathrm{b}}$ \\
EPB & $72.43 \times 10^{6} \pm 2.71^{\mathrm{b}}$ & $78.63 \times 10^{6} \pm 1.42^{\mathrm{b}}$ & $77.43 \times 10^{6} \pm 1.72^{\mathrm{b}}$ & $98.66 \times 10^{6} \pm 2.20^{\mathrm{c}}$ \\
SD & $89.33 \times 10^{6} \pm 1.15^{\mathrm{e}}$ & $114.66 \times 10^{6} \pm 2.18^{\mathrm{e}}$ & $112.66 \times 10^{6} \pm 1.20^{\mathrm{e}}$ & $95.33 \times 10^{6} \pm 1.63^{\mathrm{d}}$ \\
RMW & $91.66 \times 10^{6} \pm 1.70^{\mathrm{c}}$ & $101.00 \times 10^{6} \pm 2.20^{\mathrm{c}}$ & $104.00 \times 10^{6} \pm 1.32^{\mathrm{c}}$ & 9 \\
\hline
\end{tabular}

Values show mean of triplicates analysis \pm standard deviation. Figure with different superscripts down the column were significantly different according to Duncan new multiple range test at $\mathrm{P} \leq 0.05$.

$\mathrm{CP}=$ Cassava peel; $\mathrm{EPB}=$ Empty palm bunch; $\mathrm{SD}=$ saw dust; RMW= Rice mill waste

Total heterotrophic fungal populations during the four months of sampling under different treatments showed that fungal count was highest at 1 st month and gradually reduced at $2^{\text {nd }}, 3^{\text {rd }}$ and $4^{\text {th }}$ months respectively. Fungal count with maximum value was recorded in plot amended with $5 \mathrm{t} /$ ha cassava peel $\left(24.33 \mathrm{x} 10^{2} \pm 1.25 \mathrm{CFU} / \mathrm{g}\right)$, followed by $5 \mathrm{t} / \mathrm{ha}$ saw dust $\left(23.66 \times 10^{2} \pm 1.73 \mathrm{CFU} / \mathrm{g}\right), 5 \mathrm{t} / \mathrm{ha}$ rice mill waste $\left(19.53 \times 10^{2} \pm 1.65 \mathrm{CFU} / \mathrm{g}\right), 5 \mathrm{t} / \mathrm{ha}$ empty palm bunch $(17.00$ $\left.\mathrm{x} 10^{2} \pm 1.16 \mathrm{CFU} / \mathrm{g}\right)$ and minimum value recorded in control $\left(11.33 \times 10^{2} \pm 1.19 \mathrm{CFU} / \mathrm{g}\right)$ at $1^{\text {st }}$ month (April) of sampling; while $4^{\text {th }}$ month (July) showed total decline in fungal population and it is recorded as the least of the counting compared to other months. The sequence is $5 \mathrm{t} / \mathrm{ha} \mathrm{CP}\left(20.61 \times 10^{2} \pm 1.19 \mathrm{CFU} / \mathrm{g}\right), 5 \mathrm{t} / \mathrm{ha} \mathrm{SD}\left(18.61 \mathrm{x} 10^{2} \pm 1.35 \mathrm{CFU} / \mathrm{g}\right), 5 \mathrm{t} / \mathrm{ha}$ RMW (14.19x10² $\pm 1.65 \mathrm{CFU} / \mathrm{g}), 5 \mathrm{t} / \mathrm{ha}$ EPB $\left(12.28 \times 10^{2} \pm 1.45 \mathrm{CFU} / \mathrm{g}\right)$ and control $\left(11.33 \times 10^{2} \pm 1.17 \mathrm{CFU} / \mathrm{g}\right)$. Cassava peel (CP) promoted fungal growth in the soil with a significant variation between the treated plot as well as control plot at $P \leq 0.05$ (Table 3 ).

Table 3. Effect of different treatment applications on total heterotrophic fungal mean count (CFU/g) in 2019 cropping season

\begin{tabular}{ccccc}
\hline & & Sampling period & & \\
Treatments & April & May & June & $11.33 \times 10^{2} \pm 1.17^{\mathrm{a}}$ \\
\hline Control & $11.33 \times 10^{2} \pm 1.19^{\mathrm{a}}$ & $11.33 \times 10^{2} \pm 1.15^{\mathrm{a}}$ & $11.33 \times 10^{2} \pm 1.52^{\mathrm{a}}$ & $20.61 \times 10^{2} \pm 1.19^{\mathrm{dc}}$ \\
CP & $24.33 \times 10^{2} \pm 1.25^{\mathrm{d}}$ & $23.66 \times 10^{2} \pm 1.25^{\mathrm{d}}$ & $22.16 \times 10^{2} \pm 1.25^{\mathrm{d}}$ & $12.28 \times 10^{2} \pm 1.45^{\mathrm{b}}$ \\
EPB & $17.00 \times 10^{2} \pm 1.16^{\mathrm{b}}$ & $16.66 \times 10^{2} \pm 1.55^{\mathrm{cb}}$ & $14.26 \times 10^{2} \pm 1.35^{\mathrm{c}}$ & $18.61 \times 10^{2} \pm 1.35^{\mathrm{e}}$ \\
SD & $23.66 \times 10^{2} \pm 1.73^{\mathrm{e}}$ & $21.66 \times 10^{2} \pm 1.35^{\mathrm{e}}$ & $20.43 \times 10^{2} \pm 1.42^{\mathrm{e}}$ & $14.19 \times 10^{2} \pm 1.65^{\mathrm{cd}}$ \\
RMW & $19.53 \times 10^{2} \pm 1.65^{\mathrm{c}}$ & $16.00 \times 10^{2} \pm 1.17^{\mathrm{bc}}$ & $16.10 \times 10^{2} \pm 1.31^{\mathrm{b}}$ & \\
\hline
\end{tabular}

Values show mean of triplicates analysis \pm standard deviation. Figure with different superscripts down the column were significantly different according to Duncan new multiple range test at $\mathrm{P} \leq 0.05$.

$\mathrm{CP}=$ Cassava peel; $\mathrm{EPB}=$ Empty palm bunch; $\mathrm{SD}=$ saw dust; $\mathrm{RMW}=$ Rice mill waste

Table 4. Microorganisms isolated from the soil sample and their percentage occurrence (CFU/g)

\begin{tabular}{|c|c|c|c|c|c|c|}
\hline Organisms isolated & Control & $\mathrm{CP}$ & ЕРВ & SD & RMW & \% Occurrence \\
\hline Staphylococcus aureus & + & + & + & + & + & $100 \%$ \\
\hline Proteus mirabilis & + & + & + & + & + & $100 \%$ \\
\hline Escherichia coli & + & + & + & + & + & $100 \%$ \\
\hline Micrococcus varians & + & + & + & + & + & $100 \%$ \\
\hline Pseudomonas aeruginosa & + & + & + & + & + & $100 \%$ \\
\hline Bacillus subtilis & + & + & - & + & + & $80.0 \%$ \\
\hline Aspergillus niger & + & + & + & + & + & $80.0 \%$ \\
\hline Rhizopus spp & - & + & + & + & + & $80.0 \%$ \\
\hline Penicillum spp & + & + & + & + & - & $80.0 \%$ \\
\hline Lactococcus lactis & - & - & + & + & + & $60.0 \%$ \\
\hline Acinetobactercalcoaceticus & - & + & - & + & + & $60.0 \%$ \\
\hline Fusarium spp & - & + & + & - & + & $60.0 \%$ \\
\hline Enterobacter cloacae & - & + & + & - & + & $53.0 \%$ \\
\hline Salmonella sp & - & - & - & - & + & $40.0 \%$ \\
\hline Mucor spp & - & + & - & + & - & $40.0 \%$ \\
\hline Aureobasidium spp & - & + & - & + & - & $40.0 \%$ \\
\hline
\end{tabular}

$(+)$ = present of microbes; $(-)$ = absent of microbes; $\mathrm{CP}$ = Cassava peel; $\mathrm{EPB}=$ Empty palm bunch; $\mathrm{SD}=$ saw dust; RMW= Rice mill waste 
The increase in fungal population value noticed in the cassava peel plot might be as a result of adequate supply in organic carbon content for microbial growth and utilization. Lowest values of fungal count were recorded on control plot across the 4 sampling periods. Study showed that increased soil $\mathrm{pH}$ in the acidic range caused a shift towards dominance of the bacterial community, while fungal communities were unaffected [20]. Fungal population in soil at harvest was low as compared to bacterial population.

Microorganisms isolated and their percentage occurrence include; Staphylococcus aureus (100\%), Proteus mirabilis (100\%), Escherichia coli (100\%), Micrococcus varians (100\%), Pseudomonas aeruginosa (100\%), Bacillus cereus (80\%), Aspergillus niger (80\%), Rhizopus spp (80\%), Penicillium spp (80\%), Lactococcus lactis (60\%), Acinetobacter calcoaceticus (60\%), Fusarium (60\%), Enterobacter cloacae (53\%), Salmonella sp (40\%), Mucor spp (40\%) and Aureobasidium spp $40 \%$ (Table 4). Application of different organic agro-wastes manure promoted biological and microbial diversity with gram negative bacteria dominating compared to gram positive bacterial as well as fungi, also the ratio of the Gram-negative and Gram-positive bacteria was related to quality of organic matter and its content in the soil and this might reflect the loss of easily decomposable materials. The enhanced biological activities in the manure treated soil are evidenced by relatively high carbon content and enzyme activities. [16] reported that changes in nutrient composition have the potential to directly or indirectly affect the microbial community in the soil, thereby stimulating the development of certain group of microorganisms, and increase microbial count and diversity.

Hausa potato (solenostemon rotundifolius) stem height recorded an increased in height starting from 5 weeks after planting (WAP). At $16 \mathrm{WAP}$, plot amended with $5 \mathrm{t} / \mathrm{ha}$ saw dust (SD) recorded the highest stem height of $31.40 \mathrm{~cm}$, followed by 5 t/ha cassava peel $(28.52 \mathrm{~cm}), 5 \mathrm{t} / \mathrm{ha}$ rice mill waste $(29.62 \mathrm{~cm})$ and $5 \mathrm{t} / \mathrm{ha}$ empty palm bunch $(27.47 \mathrm{~cm})$, while control plot recorded10.62 cm height (Table 5).

Yield of hausa potato with plot of $5 \mathrm{t} / \mathrm{ha}$ saw dust recorded the highest yield of $2.9 \mathrm{t} / \mathrm{ha}$, followed by plot with $5 \mathrm{t} / \mathrm{ha}$ cassava peel (2.5 t/ha), while plot with $5 \mathrm{t} / \mathrm{ha}$ rice mill waste (2.4 t/ha), and $5 \mathrm{t} / \mathrm{ha}$ empty palm bunch ( $2.3 \mathrm{t} / \mathrm{ha})$, whereas control recorded the lowest value of $2.1 \mathrm{t} / \mathrm{ha}$ (Table 6). The result indicates that application of organic agro wastes did not only result in the immobilization of plant available nutrients but increased nutrient turnover both in microbial biomass and activity. Research by [21] stated the importance of substituting costly mineral fertilizers with manure and other organic substrates as part of the improvement of soil biological productivity and crop yield. Also [22] [23], reported changes in soil composition due to agricultural management practices can have large impacts on crop health and productivity. Organic agro wastes amendment has essential nutrients needed for improvement of soil fertility, plant growth and yield of Hausa potato (solenostemon rotundifolius poir). Therefore, there is need for proper utilization of organic agro-wastes in the improvement of soil fertility status, microbial activity and increased crop yield.

Table 5. Hausa potato stems height $(\mathrm{cm})$ as dependent upon treatment

\begin{tabular}{|c|c|c|c|c|c|}
\hline \multirow[t]{2}{*}{ Treatments } & \multicolumn{3}{|c|}{ Stem height } & \multirow[b]{2}{*}{ July } & \multirow[b]{2}{*}{ Mean } \\
\hline & April & May & June & & \\
\hline Control & 4.7 & 9.5 & 14.1 & 14.3 & 10.62 \\
\hline $\mathrm{CP}$ & 10.9 & 29.7 & 36.8 & 36.7 & 28.52 \\
\hline EPB & 8.6 & 26.5 & 37.3 & 37.5 & 27.47 \\
\hline SD & 11.2 & 32.6 & 40.9 & 40.9 & 31.40 \\
\hline RMW & 10.8 & 30.4 & 38.6 & 38.7 & 29.62 \\
\hline
\end{tabular}

$\mathrm{CP}=$ Cassava peel; $\mathrm{EPB}=$ Empty palm bunch; $\mathrm{SD}=$ saw dust; RMW= Rice mill waste

Table 6. Hausa potato yield (t/ha) as dependent upon treatment

\begin{tabular}{ccc}
\hline Treatments & Root yield (t/ha) \\
\hline Control & 2.1 \\
CP & 2.5 \\
EPB & 2.3 \\
SD & 2.9 \\
RMW & 2.4 \\
\hline
\end{tabular}

$\mathrm{CP}=$ Cassava peel; $\mathrm{EPB}=$ Empty palm bunch; $\mathrm{SD}=$ saw dust; $\mathrm{RMW}=$ Rice mill waste

\section{Conclusion}

The present investigation showed that all the agro organic amendment applied had great impact on soil microbial community and its activity, and these would help provide a better understanding of the importance of these organic fertilizers in promoting soil microbial activities, growth and crop yield. This study has shown that agro-wastes contain 
plant nutrient elements that can improve soil fertility status, microbial activity and increase crop yield. Beneficial effects occurred even when the organic agro waste amendments were only a small portion of the total amounts supplied to the soil throughout the 4 months, suggesting that a shift to more sustainable production systems could significantly improve soil fertility while maintaining crop yield at all treatment levels. We therefore recommend application of 5 t/ha saw dust agro waste for successful integrated crop production system in order to promote biological and microbial activities, soil fertility, growth and yield of Hausa potato (Solenostemon rotundifolius poir) production in an ultisol of Southeastern Nigeria under the agro environmental conditions specified in this study.

\section{References}

[1] Oladipo, O. G., Olayinka, A., and E. A. Aduayi. (2005). Effects of organic amendments on microbial activity, N and P mineralization in an Alfisol. Environ. Manage. J., 2: 30-40.

[2] Ayeni, L. S. and Adeleye, E. O. (2011). Soil nutrient status and nutrient interactions as influenced by agro wastes and mineral fertilizer in incubation study in the South West Nigeria. Int. Journ. Soil Sci., 6: 60-68.

[3] Drinkwater, L. E. and Snapp, S. (2007). Understanding and managing the rhizosphere in agroecosystems. In: Cardon Z. G., Whitbeck J. L. (Eds.), the rhizosphere: an ecological perspective. Elsevier Academic Press, London, UK, pp. 127-153.

[4] Paul, E. (2007). Soil microbiology, ecology, and biochemistry, 3rd ed. Elsevier Academic Press.

[5] Kumar, U., Nayak, A. K., Shahid, M., Gupta, V. V. S. R., Panneerselvan, P., Mohanty, S., Kaviraj, M., Kumar, A., Chatterjee, D., Lal, B., Gautam, P., Tripathi, R., and Panda, B. B. (2018). Continuous application of inorganic and organic fertilizers over years in paddy soil alters the the bacterial community structure and its influence on rice production. Agric. Ecosyst. Environ. 22: 5-75.

[6] Saeki, M. and Toyota, K. (2004). Effect of bensulfuron-methyl on the soil bacterial community of a paddy soil microcosm, Biol. Fertile. soils. (40): 110-118.

[7] Bremner, J. M. (1996). Methods of soil analysis part—chemical methods, Nitrogen-Total In: D. L. Madison, USA. Pp. 1085-1122.

[8] Association of Official Analytical Chemist (A.O.A.C). (1990). Official methods of Analysis. $2^{\text {nd }}$ Edition. Washington D.C.

[9] Anderson, J. P. E. and Domasch, K. H. (1958). A physiological method for the quantitative measurement of microbial biomas in soil. Soil Boil. Biochem. 10: 215-221.

[10] Scharlau Microbiology: Handbook of Microbiological Culture Media (2000). Ref. 1-051 (Czapek-Dox), p. 87, Sixt Int. Edition, Barcelona, Spain.

[11] Nwafor, O. E., Adepoju, S. O., Mba, A. A., Okonkwo, M., Emefiene, C. M., and Aminu, K. (2010). The effect of manual weeding intervals on the yield of water melon (Citrullus lanatus) in Jos Metropolis, Nigeria. Proceedings of the 24th Annual National Conference of Farm Management Association of Nigeria, September 6-9, 2010, Adamawa State University, Mubi, Nigeria, pp: 35-38.

[12] Kang, G. S., V. Beri, O. P. Rupela, and Sidhu, B. S. (2005). A new index to assess soil quality and sustainability of wheat based cropping systems. Biol. Fertil. Soils, 41: 389-398.

[13] Arancon, N. Q., Edwards, C. A., and Bierman, P. (2006). Influences of vermicomposts on field strawberries: Part 2. Effects on soil microbiological and chemical properties. Bioresour Technol, 97: 831-840.

[14] Dinesh, R., Srinivasan, V., Hamza, S., and Manjusha, A. (2010). Short-term incorporation of organic manures and biofertilizers influences biochemical and microbial characteristics of soils under an annual crop [Turmeric (Curcuma longa)]. Bioresour Technol 101:4697-4702

[15] Girvan, M. S., Bullimore, J., Ball, A. S., Pretty, J. N., and Osborn, A. M. (2004). Response of active bacterial and fungal communities in soil under winter wheat to different fertilizer and pesticide regiments. Applied Environental Microbiology 70 : 2692-2701.

[16] Iwoh, E. F., Onyegbula, O. D., Ibok, I. U., and Peter U. U. (2020). Assessment of the Short-term effect of different fertilizers on soil Microbial population, Biomass Carbon and microbial diversity in Ginger (Zingiber officinale) based soil. Intl. Journal of Research and Innovation in Applied Science.5:5 pp. 55-59.

[17] Mader, P., Fliebbach, A., Dubois, D., Gunst, L., Fried, P., and Niggli, U. (2002). Soil fertility and biodiversity in organic farming. Science, 296: 1694-1697.

[18] Parham, J. A., Deng, S. P., Da, H. N., Sun, H. Y., and Raun, W. R. (2003). Long-term cattle manure application in soil. II. Effect on soil microbial populations and community structure. Biol. Fertil. Soils, 38: 209-215.

[19] Li, J., Yang-ting, L., Xiang-dong, Y., Jian-jun, Z., Zhian, L., and Zhao, B. Q. (2015). Microbial community structure and functional diversity are associated with organic carbon availiability in an agricultural soil. Journal Intl. Agric. Pp. 61229-61231.

[20] Pennanen, T. (2001). Microbial communities in boreal coniferous forest humus exposed to heavy metals and changes in soil $\mathrm{pH}$ - a summary of the use of phospholipid fatty acids biolog and ${ }^{3} \mathrm{H}$-thymidine incorporation methods in field studies. Geoder- 
ma, 100: 91-126.

[21] Manqiang, L., Feng, H., Xiaoyun, C., Qianru, H., Jiaguo, J., Bin, Z., and Huixin, L. (2009). Organic amendmenes with reduced chemical fertilizer promote soil microbial development and nutrient availability in a subtropical paddy field. The influence of quality, type and application time of organic amendments. Appl. Soil Ecol. 42: 166-175.

[22] Chaparro, J. M., Sheflin, A. M., Manter, D. K., and Vivanco, J. M. (2012). Manipulating the soil microbiome to increase soil health and plant fertility. Biol Fertil Soils 48:489-499.

[23] Franco-Otero, V. G., Soler-Rovira, P., Hernández, D., López-de-Sá, E. G., and Plaza, C. (2012). Short-term effects of organic municipal wastes on wheat yield, microbial biomass, microbial activity, and chemical properties of soil. Biol Fertil Soils 48: 205-216. 